\title{
ROMAN INGARDEN
}

AND HIS TIMES 


\title{
ROMAN INGARDEN AND HIS TIMES
}

\author{
edited by \\ Dominika Czakon \\ Natalia Anna Michna \\ Leszek Sosnowski
}

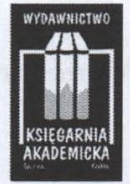

Kraków 2020 
(C) Copyright by Wydział Filozoficzny UJ and Dominika Czakon, Natalia Anna Michna, Leszek Sosnowski, Kraków 2019

Review

Jeff Mitscherling

Władysław Stróżewski

Proofreading

Keith Horechko

Cover design

Agnieszka Gogola

ISBN 978-83-8138-103-1 (print)

ISBN 978-83-8138-210-6 (on-line, pdf)

The publication is financed by the Ministry of Science and Higher Education of the Republic of Poland under the program "DIALOG” in the years 2019-2020

KSIĘGARNIA AKADEMICKA

ul. św. Anny 6, 31-008 Kraków

tel./faks: 12 431-27-43, 12 421-13-87

e-mail: akademicka@akademicka.pl

https://akademicka.pl 


\section{Table of contents}

1. Simona Bertolini

Ingarden and the "Layered" Anthropologies of His Times

2. Virgil W. Brower

Innards of Ingarden. Secretion, Permeation \& Physiology of Time

3. Wojciech Chojna

Roman Ingarden and Edmund Husserl.

Idealism, Identity, and Relativism

4. Dominika Czakon, Natalia Anna Michna, Leszek Sosnowski

On the Difficult Academic and Personal Relationship

of Roman Ingarden and Kazimierz Twardowski

5. Nigel Dower

Situated Freedom. Thoughts on its Importance,

Variability and Malleability

6. Sérgio Fernandes

Husserl's "Idealism". Intentional Externalist Adverbialism

and Epistemological Disjunctivism

7. Matthew Gladden

Ingarden's Systems-Theoretical Philosophical Anthropology

as a Tool for Analyzing the Technological Posthumanization

of Persons and Societies

8. Hans Grelland

Phenomenology and Physics. Hermann Weyl (1885-1955)

9. Rômulo Eisinger Guimarães

From "Unbestimmtstellen" to "Leerstellen" and "campo di possibilità interpretative". How Current is Ingarden's Theory of Literature? 
10. Ineta Kivle

Music in the Phenomenology of Roman Ingarden

and Alfred Schutz

\section{Hélène Leblanc}

The Semiotic Foundation of Ingarden's Analysis of Music

12. Olivier Malherbe

Artistic Creation in Ingarden's Thought

\section{Andrzej Półtawski}

Roman Ingarden's Dramatic Pursuit of Philosophical Truth

14. Małgorzata A. Szyszkowska

Roman Ingarden's Theory of Aesthetic Experience.

From Idea to Experience and Back

15. Edward M. Świderski

Ingarden and the Quandary of Musical Ontology

\section{Jan Woleński}

Philosophical Significance of the Lebenswelt.

An Analytical Approach and a Defence of Naturalism

Index 


\title{
INETA KIVLE
}

\author{
University of Latvia
}

\section{Music in the Phenomenology of Roman Ingarden and Alfred Schutz}

\begin{abstract}
Ingarden's and Schutz's approaches to music are not only two various phenomenologies of music. They also justify two branches of the development of Husserl's phenomenology - one shows how the phenomenological method of reduction is applicable to constitution of essences of particular phenomena, in this case to music; the other accentuates how the concepts of life-world and intersubjectivity are developed in the context of music. This study analyzes how Husserl's phenomenology influences Ingarden's and Schutz's views on music; how such basic notions of phenomenology as intentionality, constitution of essences, intersubjectivity, life-world, and internal time modify their philosophical conceptions of music. Ingarden employs a method of phenomenological reduction for the identification of ontological structures and modes of being of the musical work, and shows how the essence of music dwells in the musical work itself, while Schutz emphasizes the common social experience of music and analyzes music as an intersubjective and social phenomenon. The philosophers share two approaches in common: (a) they both turn away from transcendental to realist phenomenology and (b) they both use phenomenological concepts for descriptions of music. The primary resources of the study are Ingarden's The Musical Work and Schutz's Making Music Together. A Study in Social Relationship and Mozart and Philosophers. Comparing the views expressed in these works we see both similar and different approaches to phenomenological interpretation of music.
\end{abstract}


Key words: music, time, Husserl, Ingarden, Schutz, phenomenology

Philosophical thinking about music and listening to music constitute different meanings of music. In the process of listening to music we do not analyze essential structures of music but enjoy sonority; when we begin to analyze what we have listened to, we move to a theoretical approach, intentions are no longer directed to the sounding phenomena but to our thoughts, impressions and emotions. Husserl writes: "Just as a phantasied sound is not a sound but the phantasy of a sound, or just as tonal sensation and tonal phantasy are fundamentally different and are not to be considered as possibly the same, except the difference in interpretation, likewise primary, intuitively remembered sound is intrinsically something other than the perceived sound, and the primary remembrance of sound is something other than the sensation of sound." If we listen to music, we experience the melody; however, if we think about the phenomenon of music, we are in a phenomenological attitude and practice philosophical thinking. If we constitute structures of internal time consciousness, we explore the method of phenomenological thinking. As an object the heard melody is the same in both situations - in listening to the melody and in thinking about it - but the melody appears differently at the two times because it is grasped by different intentions and constitutes different meanings: "The sound itself is the same but in the way "that it appears" the sound is continually different." 2

The development of the phenomenology of music would perhaps have been unlikely without Husserl's contribution. While he does not write about music directly, he provides the impulse to think about music as a time-object, intentional object and meaningful intersubjective phenomenon, showing ontological structures of the phenomenon. If the ontological structure of any phenomenon is a dynamic correlation between objectivity and appearance, then what are the exclusive features of

1 Edmund Husserl, The Phenomenology of Internal Time-Consciousness, ed. Martin Heidegger, trans. James S. Churchill (Bloomington: Indiana University Press, 1964), 54.

2 Ibid., 45. 
the phenomenon of music that differentiate it from other phenomena? Husserl's descriptions of sound as a temporal object and his elucidation of the structure of internal time consciousness give clear phenomenological analyses of music. Husserl's phenomenology describes sound as it is given in experience, and alongside his descriptions of sound he elucidates ontological structures, essences, formation of meanings, intentionality, the phenomenal time of experience, and the internal time of time-objects. Alongside descriptions of sound Husserl's approach constitutes intentional structures of internal time consciousness.

The question: "How do 'I' perceive music?" is the beginning of the phenomenological constitution of music. Later phenomenologists of music do not repeat the question: How is music as a meaningful phenomenon given in the stream of consciousness? They do not analyze the constitution of meaning and the pure 'I', nor the techniques of phenomenological and transcendental reduction, bracketing and reflection. They turn away from Husserl's revelations of transcendental phenomenology and create realistic phenomenology in analysis of particular phenomena. Both Ingarden and Schutz pay critical attention to phenomenological transcendentalism: Ingarden criticizes Husserl for dependence on the world of consciousness; however, he explores reduction as a methodological way for identification of ontological structures and gives a realistic description of the work of art. Schutz suggests that this is not an appropriate approach for the theoretical explication of social structures and the phenomenology of music.

\section{Ingarden's Realistic Phenomenology of Music}

Ingarden does reject Husserl's views regarding the constitution of essence by turning away from the natural attitude to the phenomenological attitude, the slogan "back to things themselves", phenomenological reduction, and reflection. Ingarden explores these cognitions as evidently given; he does not repeat them but concentrates on the musical work itself.

Ingarden's approach is centred upon the question: How is music in itself? He is the first to elaborate such detailed analyses of the ontological structures of works of art: literature, music, painting, architecture, and film. 
Because of the belated translation of The Musical Work into English, the references of later phenomenologists of music to Ingarden's analysis were limited: The Musical Work was written shortly after The Literary Work of Art, in about 1928, translated into German in 1961, and only in 1989 into English. In Krakow in 1961 Ingarden wrote: "In 1933 I translated a large part of the essay on "The Musical Work" into Polish and published it under the title The Problem of the Identity of the Musical Work."' Ingarden's ontological analyses have influenced Lawrence Ferrara's studies in phenomenology and hermeneutics of music. In Philosophy and the Analysis of Music (1991) Ferrara makes reference to Ingarden's contribution: "Ingarden's insight can be brought to bear on Analysis of musical space and time. Musical space is not the objective space of the physio-temporal world or the ideal space of geometry. Instead, it is a unique space which occurs in a unique musical time. [...] Ingarden's theory of the literary work of art supports and enriches my conception of the organicity of multi-layers of musical significance. He considers, as I do, the independence of each stratum as well as its potential for dependence and synthesis with other structures."

Such works as D. Ihde's Listening and Voice. A Phenomenology of Sound (1976), T. Clifton's Music as Heard: A Study in Applied Phenomenology (1983), and J. Smith's The Experiencing of Musical Sound. Prelude to a Phenomenology of Music (1979) continue Ingarden's approach to music without making reference to Ingarden's contribution. Like Ingarden, musical phenomenologists Clifton and Smith follow the principle of starting from music itself. Clifton writes that both "phenomenology and contemporary music teach us that rigorous analysis requires only one thing: to listen

${ }^{3}$ Roman Ingarden, Ontology of the Work of Art: The Musical Work, the Picture, the Architectural Work, the Film, trans. Raymond Meyer, and John T. Goldthwait (Athens, OH: Ohio University Press, 1989), ix. Lawrence Ferrara gives characterization of translations of Ingarden's works: “Three important books concerning aesthetics by Ingarden are translated into English. The one on music is perhaps the least useful for a phenomenology of music due to its often unclear and awkward translation from the Polish edition; Ingarden originally published this work in a much clearer German edition. The other two, which deal with the literary work of art, provide a rich source material for musical aesthetics." Lawrence Ferrara, Philosophy and the Analyses of Music: Bridges to Musical Sound, Form, and Reference (New York: Excelsior Music Publication, 1991), 168.

${ }^{4}$ Ferrara, Philosophy and the Analyses of Music, 169-70. 
carefully to what is given, making sure that what is given is the music itself". Smith affirms that phenomenological thinking is an attempt to let the musical phenomenon speak for itself and "in seeking the full phenomenological spectrum we may have to do more than just look into things. We may have to listen to things." ${ }^{1}$ Ingarden is fascinated by the possibility of discovering the ontological structures of works of art. His concentration on the musical work in itself as a centre of all possible modes of existence of music is built upon Husserl's slogan back to the things themselves, allowing music to be as it is. In a letter to Twardovski in 1922 , Ingarden writes about his own philosophical interest in ontology as a central direction for constitution of an object's identity: "One must know what the object is and what the object's property is, that is to say, what the object's identity is, and what the relationship between objects is [...]. In other words, in order to judge the role, the meaning of the categorical structures whether, for example, it is a certain fundamental structure embodied in every autonomous object." In the foreword to the German edition of Ontology of the Work of Art Ingarden writes that his studies on music, architecture and painting stand in very close relation to The Literary Work of Art. "The principal problem with which I was concerned at that time was that of the structure and the mode of being of works of art as determinately constituted, purely intentional objectivities." Ingarden focuses on the questions: How can the same thing disclose itself to us in qualitatively different performances? What permits music to show itself as self-identical in different performances? In the Introduction to The Musical Work Ingarden observes: "Because the musical work is not an ideal object, it does not follow that it is a real object. Thus it will later be necessary to determine positively what its mode of existence

5 Thomas Clifton, Music as Heard: A Study in Applied Phenomenology (New Haven: Yale University Press, 1983), x.

${ }^{6}$ F. Joseph Smith, The Experiencing of Musical Sound: A Prelude to a Phenomenology of Music (New York: Gordon and Breach, 1979), 28.

7 Friederike Moltmann, and Markus Textor, Act-Based Conceptions of Propositional Content: Contemporary and Historical Perspectives (New York: Oxford University Press, 2017).

8 Ingarden, Ontology, x. 
is." As a starting point for the clarification of the modes of existence of music Ingarden explores correlations between the musical work (objectivity) and its performances (appearances). "Each performance of a musical work is an individual process and therefore also a temporal object, which is clearly situated in intersubjective concrete time". ${ }^{10}$ Each performance is an acoustic process that can happen only once; it is located in space and given to us in hearing.

Ingarden's turn away from transcendental phenomenology to realist phenomenology uncovers the ontological givenness of the musical work as a purely intentional object of a special kind that exists between the real and the ideal and includes the creative acts of the composer, sound events, performances, and notations. The musical work is neither a real nor an ideal object and the composer is unable to put the all intentions of the musical work into the score. The musical work is not identifiable with notation or any other real thing - it is ontically founded by the intentions of the composer, musicians and listeners as well as by each individual performance. The identity of the musical work is founded in formal structures that include objects, processes and relations. Ingarden characterizes the work of music as a reduced phenomenon with three chained elements: ideal-real, pure intentionality, and immanent internal time. Ingarden writes: "Every real process which occurs in the real world takes place in a definite, nonrepeatable segment of time." ${ }^{11} \mathrm{He}$ concludes that the musical work is quasi-temporally determined and differs from events and processes of the real world taking place outside the work in real, objective time.

The quasi-temporality of the musical work is grounded in complete delimitation and closures of the work - the pure musical work makes no reference to the real world - absolute music does not express or present anything that goes beyond the tones. For clarification of the quasi and supra existence of the work of music Ingarden offers a comparison with architecture, plastic arts and painting:

\footnotetext{
9 Ibid., 11.

${ }^{10}$ Ibid., 8.

11 Ibid., 37-8.
} 
The architectural work, a church, say, is in point of fact bound up with reality $[\ldots]$ and made of material that forms a constituent part of the real world. [...] as a "building," the architectural work is intended to be at a definite place on the ground and to be connected with it. It is built out of heavy material [...].

To a certain extent the situation is similar for the works of other arts. Works of plastic art, for example, usually have a pedestal, a "base." [...] A painting is of course usually set off by a "frame" [...]. ${ }^{12}$

Ingarden stresses visibility - real is what is seen, such physical properties as weight, hardness, etc. However, it is known that sound also possesses properties of physical reality, such as waves and vibrations of sounding air. In response to the question, What kind of reality is immanent to music?, Ingarden's analyses lead him to answer that "the musical work, as distinct from its performances, is not a real object, and [...] it is in principle distinct from both natural acoustic phenomena and artificial sound signals."13

Ingarden employs the method of reduction in a specific way - it is not possible to reduce the musical work solely to sounding or to performance, or to scores. The musical work is between the real and the ideal, where reality in this case is sought in relation with one or another kind of works of art. In music reality is not the same as it is in architecture. The reality of music is determined by its ontological combinations indicating a confluence of all the elements of the musical work: acoustic moments of the musical work, such as tonal foundation and rhythmic qualities; non-acoustic elements, such as temporal structure; the phenomenon of movement; forms of tone formations; and emotional qualities. These combinations show that the musical work is a purely intentional object "which has its source of being in the creative acts of the composer and its ontic foundation in the score" ${ }^{14}$ Musical works, as purely intentional objects, would not ever exist without the composer who created them and without the listeners who apprehend them aesthetically. The content of the musical work deter-

\footnotetext{
12 Ibid., 44-5.

13 Ibid., 46.

14 Ibid., 90-1.
} 
mines emotions and aesthetic value - great musical works give us access to emotional qualities that we otherwise could not encounter.

\section{Music Itself and Its Transcendence}

The musical work itself is "de-individualized", it is in its purity and as such it differs from the performance of it. Ingarden writes that: "[the musical work] remains at the same time something that is transcendental to all concrete individual mental experiences"; "it is neither something 'subjective' nor something mental." 15 Congenially to Ingarden, Schutz agrees that music can be transcendental. Characterizing Mozart's music he writes: "It might be assumed that philosophers, following Schopenhauer's views, would turn to Mozart's music as an embodiment of the universe and an expression of transcendental experience as such." ${ }^{16}$ His essay on Mozart's music gives a brief introduction to what music is in philosophy: "From the Pythagoreans, from Plato and St. Augustine to Bergson and Santayana, philosophers have concerned themselves with music as one of the ways in which man expresses the basic experience of transcendence constitutive of his place within and his attitude toward the cosmos."17

While the musical transcendence that Schutz writes about may be something that goes beyond inner experience toward infinity, a transcendental approach is not the right way to analyze music as a social phenomenon; realist phenomenology is more appropriate for the description of particular phenomena. Schutz differentiates music as a sounding event from music as an object of philosophical thinking. He does not agree with the position that intersubjectivity is a problem that must be viewed on a transcendental level. In spite of his critical view of Husserl's transcendental approach, Schutz's social philosophy as well as his views on music are based on Husserl's concepts of the world, intersubjectivity and the life-world.

15 Ibid., 93.

16 Alfred Schutz, "Mozart and the Philosophers," Social Research 23, no. 2 (1956): 219-42.

17 Ibid., 220. 


\section{Schutz's Social Phenomenology of Music}

Schutz's phenomenology moves away from the musical work itself to music as a phenomenon incorporated in social activities and processes of communication. Ingarden's suggestions that creative acts of the composer must be executed by the musicians and listeners resonate with Schutz's description of music as a social phenomenon forming a meaningful space and time shared in common by composer, musicians, and listeners. "The creative act of the composer is merely a discovery in the same world of sounds that is accessible exclusively to the society of musicians. It is precisely because the composer accepts the conventions of this society and because he penetrates more deeply into them than others, that he can make his discoveries."18

In Crisis of European Man Husserl writes: "To live as a person is to live in a social framework, wherein I and we live together in a community and have the community as a horizon. [...] Here the world is not to be taken in a physiological sense but in the broadest sense, creating culture within historical continuity." ${ }^{19}$ Husserl's concept of the lifeworld makes possible the interpretation of music in the context of everyday life containing cultural objects, things and human social experience. Such Husserlian expressions as "we live together manifesting spiritual creativity" resonate with the concept of making music together in the framework of a social relationship that Schutz characterizes as a highly complicated structure. $\mathrm{He}$ draws his philosophical field of music study as an "analysis of the particular character of all social interactions of the musical process that is not aimed at problems of the so-called sociology of music, nor is it concerned with the phenomenology of musical experience." 20

In Making Music Together Schutz analyzes Maurice Halbwah's views on collective memory and agrees with him that musical communication

18 Idem, "Making Music Together: A Study in Social Relationship," Social Research 18, no. 1 (1951): 81.

19 Edmund Husserl, "Philosophy and the Crisis of European Man," lecture delivered by Edmund Husserl, Vienna, 10 May 1935; therefore often referred to as: "The Vienna Lecture," accessed April 6, 2019, http://www.markfoster.net/struc/philosophy_ and_the_crisis_of_european_man.pdf.

20 Schutz, "Making Music," 76. 
as well as its re-creation is determined by collective memory. Schutz accentuates three stances in Halbwah's theory: the identification of musical thought with its communication; the identification of musical communication with musical language (notation); and the identification of musical notation with the social background of the musical process. The problems of musical communication and inner time are analyzed with equal importance in the context of Bergson's durée, which is the very form of existence of music. Bergsonian durée is more appropriate for the characterization of musical time than phenomenologically constituted structures of internal time consciousness - as an ongoing chain of retentions, nows, and protentions. Durée shows the time dimensions in which music occurs: "The flux of tunes unrolling in inner time is an arrangement meaningful to both the composer and the beholder." ${ }^{21}$ Outer time, contrary to inner time, is measurable - there are minutes and hours of determinate, quantifiable length. Musical time embraces the simultaneity of inner and outer time, along with the simultaneity of several events of inner time: "We have therefore the following situation: two series of events in inner time, one belonging to the stream of consciousness of the composer, the other of the beholder, are lived through in simultaneity, which is created by the ongoing flux of the musical process." 22 Schutz describes music as a common experience of musical time and a flux of musical experiences in we-relations created by composers, performers and listeners. "On the one hand, there is the inner time in which the flux of the musical events unfolds, a dimension in which each performer re-creates in polythetic steps the musical thought of the composer and by which he is also connected with the listener. On the other hand, making music together is an event in outer time, presupposing also a face-to-face relationship, that is, a community of sparce, and in this dimension it unifies the fluxes of inner time and warrants their synchronization into vivid present." ${ }^{23}$

In the process of hearing we all experience the same flux of time that is also our intersubjective time. Listeners and musicians inhabit the same

\footnotetext{
21 Ibid., 88.

22 Ibid., 92.

23 Ibid., 96.
} 
time - the sounding time of performance. Musicians and listeners are tuned to one another (face-to-face communication), they are living together through the same flux of sounds - all participants make We-unity of the musical event, they are partners in making music together and share meaningful experience of the viewed and heard. We-unity incorporates people who are present, for instance, at a concert: musicians, listeners, etc. The composer of the piece is also indirectly included in the We-unity through the intentions realized in the composition. Musical compositions and performances are covered by communication during the concert including sounding music, visually grasped things in concert halls, musicians and listeners, and the communicative environment of the event of music.

\section{Conclusions}

Comparing Ingarden's and Schutz's views on music, it is seen that descriptions of music differ depending on which philosophical concepts are used as the theoretical basis. Their phenomenologies draw upon different features of Husserl's phenomenology, yet the exploration of Husserl's concepts and the approach of realist phenomenology dedicated to investigation of the phenomenon of music are shared in common.

Ingarden's analysis of music concentrates on the essential structures of the musical work. He explores Husserl's investigation of inner time consciousness and transfers it to the ontological structure of music, revealing the supra-temporality and quasi-temporality of the musical work. Husserl's structure of the phenomenon (objectivity-appearance) is applied to the ontological structure of the musical work (ideal - real), intentionality of consciousness to the pure intentionality of the musical work; Ingarden uses the slogan "back to the things themselves" as referring to the identity of the musical work in itself. Ingarden explores the ontological structure of the constituted phenomenon (objectivity and appearance) by a method of transcendental thinking that makes possible the pure description of the identity of the musical work itself as well as affording the possibility of viewing music as extending above and beyond the limits of any particular musical work. 
Schutz's views on music resonate with his phenomenology of communication, which views music in the framework of social relationships as a phenomenon of making music together. He describes music as a common phenomenon created by composers, performers and listeners, exploring the concept of internal time-consciousness and developing new aspects of intentionality and intersubjectivity. Music is characterized in terms of intersubjective musical experience, making music together, we-relation, and the formation of an intersubjective meaning of music. Schutz's views on music are incorporated into his sociological phenomenology. Music as a social phenomenon unites a musical event of outer time with dimensions of inner times in which performers re-create the musical thought of the composer and make connections with listeners.

Phenomenological analysis of music admits several approaches to music and demonstrates that a particular philosophical understanding of music is rooted in a philosopher's views - music is as it is, music is what sounds, but theoretical interpretations of music vary.

\section{Bibliography}

- Clifton, Thomas. Music as Heard: A Study in Applied Phenomenology. New Haven: Yale University Press, 1983.

- Ferrara, Lawrence. Philosophy and the Analyses of Music: Bridges to Musical Sound, Form, and Reference. New York: Excelsior Music Publication, 1991.

- Husserl, Edmund. The Phenomenology of Internal Time-Consciousness, edited by Martin Heidegger. Translated by James S. Churchill. Bloomington: Indiana University Press, 1964.

- Husserl, Edmund. The Phenomenology of Internal Time-Consciousness, edited by Martin Heidegger. Translated by James S. Churchill. Bloomington: Indiana University Press, 2019.

- Husserl, Edmund. "Philosophy and the Crisis of European Man." Lecture delivered by Edmund Husserl, Vienna, 10 May 1935; therefore often referred to as: "The Vienna Lecture." Accessed April 6, 2019. http://www.markfoster.net/struc/ philosophy_and_the_crisis_of_european_man.pdf. 
- Ingarden, Roman. Ontology of the Work of Art. The Musical Work, the Picture, the Architectural Work, the Film. Translated by Raymond Meyer, and John T. Goldthwait. Athens, OH: Ohio University Press, 1989.

- Kivle, Ineta. Skañas filosofija [Philosophy of Sound]. Riga: LU Filozofijas un sociologijas institūts, 2009.

- Moltmann, Friederike, and Markus Textor. Act-Based Conceptions of Propositional Content: Contemporary and Historical Perspectives. New York: Oxford University Press, 2017.

- Schutz, Alfred. "Making Music Together: A Study in Social Relationship." Social Research 18, no. 1 (1951): 76-97.

- Schutz, Alfred. "Mozart and the Philosophers." Social Research 23, no. 2 (1956): $219-42$.

- Smith, F. Joseph. The Experiencing of Musical Sound: A Prelude to a Phenomenology of Music. New York: Gordon and Breach, 1979.

Ineta Kivle, Dr. phil., A Senior Researcher, Deputy director and Head of the Interdisciplinary Research Centre of Academic Library of the University of Latvia. Doctoral thesis: Sound, Speech, Voice and Music in Phenomenological Perspective (2008); author of two monographs in Latvian: Philosophy of Sound (2009); Philosophy: Theoretical and Practical Study (2011); Author of more than thirty scientific articles about XX-XXI century philosophy, ancient philosophy, interdisciplinarity. Research interests: interdisciplinarity; philosophy of sound, rhythm, colour, number.

Contacts: ineta.kivle@lu.lv; inetakivle21@gmail.com 